\title{
Penilaian Perkembangan Anak Selama Belajar dari Rumah di Era Pandemic Covid-19
}

\author{
Ayu Kemala ${ }^{\circledR}$, Arif Rohman ${ }^{1}$ \\ Pendidikan Anak Usia Dini, Universitas Negeri Yogyakarta, Indonesia( ${ }^{(1)}$ \\ DOI: $\underline{10.31004 / \text { obsesi.v6i2.1129 }}$
}

\begin{abstract}
Abstrak
Pemindahan pembelajaran ke rumah secara daring sebagai upaya mencegah penularan Covid-19 menyebabkan perubahan pada sistem pendidikan baik dari segi pembelajaran, penilaian, media dan lainnya. Penelitian ini bertujuan untuk menganalisis pelaksanaan penilaian perkembangan anak selama belajar dari rumah. Subjek penelitian 23 guru Taman Kanak-Kanak dari 10 sekolah yang melaksanakan pembelajaran jarak jauh di Sumatra Utara dengan risiko sedang penyebaran Covid -19 yaitu, Kota Medan, Deli Serdang, Serdang Berdagai, Asahan, dan Labuhan Batu. Menggunakan pendekatan deskriptif kuantitaif dengan menggunakan kuesioner sebagai teknik pengumpulan data. Kuesioner disusun menggunakan Google Form, selanjutnya tautannya disebarkan guru melalui media whatsapp. Hasil penelitian menunjukkan bahwa pelaksanaan penilaian perkembangan anak tetap dilaksanakan meski pembelajaran dilakukan dari rumah. Penilaian dilakukan dengan mengumpulkan informasi melalui laporan orang tua. Laporan orang tua berupa dokumentasi terkait proses kegiatan dan hasil kerja anak. Dikumpulkan menjadi portofolio yang berisi dokumentasi elektronik yaitu foto hasil lembar kerja, hasil karya anak, dan video unjuk kerja anak yang disatukan dalam bentuk file untuk dilakukan penilaian.
\end{abstract}

Kata Kunci: penilaian perkembangan, covid-19, pembelajaran dari rumah.

\section{Abstract}

The change of learning to home online as an effort to prevent Covid-19 transmission has certainly led to changes in the education system both in terms of learning, assessment, media and others. The purpose of this study aims to determine how the assessment of child development is carried out while learning from home. This study used a quantitative descriptive approach using a questionnaire as a data collection technique. The research subjects were 23 kindergarten teachers from 10 schools who carry out distance learning in North Sumatra with moderate risk of the spread of Covid -19, namely, Medan City, Deli Serdang, Serdang Berdagai, Asahan, and Labuhan Batu. Furthermore, the results showed that the implementation of child development assessment was still carried out even though the learning was done from home. The teacher's assessment is carried out by collecting information on child development through parents' reports. Parents' reports are in the form of documentation related to the children's work activities and results. Collected into a portfolio containing electronic documentation, namely photos of worksheets, children's work, and children's performance videos that are put together in the form of files for assessment.

Keywords: Developmental assessment, Covid-19, learning from home.

Copyright (c) 2021 Ayu Kemala,'Arif Rohman

$\triangle$ Corresponding author :

Email Address : ayukemala.2019@uny.ac.id (Yogyakarta, Indonesia)

Received 4 February 2021, Accepted 15 May 2021, Published 1 August 2021 


\section{PENDAHULUAN}

Penilaian memiliki peran penting dalam pembelajaran pada Pendidikan Anak Usia Dini (PAUD). Istilah penilaian yang diterapkan dalam PAUD secara umum mengandung arti untuk memberikan gambaran yang kaya tentang cara-cara dimana anak bertindak, berfikir dan belajar (Bowman, Donovan, \& Bums, 2001). Sejalan dengan pendapat ini, Gradner (2002) menegaskan bahwa penilaian merupakan upaya memperoleh informasi mengenai keterampilan dan potensi diri individu. Penilaian dilakukan bertujuan untuk memperoleh informasi terkait pembelajaran terutama keberhasilan pembelajaran dan prestasi belajar siswa sebagai salah satu masukan dari proses pembelajaran (Rohmadheny et al., 2019; Yus, 2015).

Prestasi belajar anak dalam Pendidikan Anak Usia Dini mengacu pada prestasi tumbuh kembang anak (Rohmadheny et al., 2019). Dengan demikian penilaian pembelajaran mengacu pada penilaian perkembangan anak. Pengukuran dilakukan berdasarkan hasil pengamatan perilaku dan karya yang dibuat anak (Maryani, 2020). Pengamatan yang dilakukan harus bersifat otentik yaitu sesuai dengan fakta yang sesungguhnya dan menyeluruh mencakup pertumbuhan dan perkembangan yang telah dicapai oleh anak selama kurun waktu tertentu. Namun, pada saat ini banyak para guru tidak bisa melakukan penilaian dengan mengamati langsung prilaku anak selama pembelajaran. Hal ini terjadi karna pemindahan aktivitas pembelajaran ke rumah akibat maraknya penularan virus Covid -19.

Berbagai Negara saat ini termasuk Indonesia sedang diguncang bencana dengan hadirnya Coronavirus Disease atau Covid -19. Virus Covid -19 memberikan dampak pada semua sisi kehidupan manusia. Covid -19 tidak hanya berdampak pada sektor kesehatan, tetapi berbagai sektor lain seperti sektor ekonomi dan sektor pendidikan. Organisasi pendidikan, keilmuan, dan kebudayaan perserikatan bangsa-bangsa atau UNESCO menindaklanjuti bahwa virus Covid -19 berdampak pada dunia pendidikan (Trisnawati \& Sugito, 2020). Banyak pemerintah telah memerintahkan institusi pendidikan untuk menghentikan pengajaran tatap muka bagi sebagian besar siswa mereka, dan mengharuskan mereka untuk beralih ke pengajaran online dan pendidikan virtual (Cichoracki, 2013). Di Indonesia, Kementrian Pendidikan dan Kebudayaan (Mendikbud) mengeluarkan surat edaran resmi No 4 Tahun 2020 tentang pelaksanaan Kebijakan Pendidikan dalam masa darurat penyebaran Covid -19, dimana salah satu ketentuan didalamnya terdapat aturan dilakukannya pembelajaran secara daring (online). Hal ini menyebabkan banyak sekolah yang tutup dan melakukan pendidikan jarak jauh secara daring dari rumah, khususnya di daerah dengan jumlah kasus penyeberan Covid -19 sedang ke tinggi.

Pemindahan belajar dari sekolah ke rumah yang dilakukan secara daring tentunya meyebabkan perubahan pada sistem pendidikan yang memberikan pengaruh terhadap aktivitas pembelajaran dan tentunya menimbulkan berbagai kendala. Salah satunya ialah Kendala pedagogi yang mulai tampak dari belum mampunya guru menyusun RPP untuk e-learning (pembelajaran daring), memilih media, memilih metode, memilih alat penilaian, dan menyelenggaran pembelajaran dengan interaksi yang optimal (Nurkolis \& Muhdi, 2020). Disamping itu guru mempersiapkan pembelajaran dimulai dari rencana pembelajaran, mengkomunikasikan dengan orang tua, dan fasilitas pendukung lainnya (Ayuni et al., 2021). Pelaksanaan penilaian menjadi salah satu kendala pedagogi yang dihdapi guru saat menerapkan pembelajaran daring.

Permendikbud 146 tahun 2014 menekankan penilaian harus bersifat otentik dimana dijelaskan di dalamnya penilaian otentik merupakan penilaian proses dan hasil belajar anak untuk mengukur ketercapaian kompetensi sikap, pengetahuan dan keterampilan yang dilakukan secara berkesinabungan, selain itu pengukuran yang dilakukan tidak hanya pada apa yang diketahui anak tetapi menekankan pada apa yang dapat dilakukan anak. Guru mengumpulkan informasi tentang setiap anak sewaktu mereka mendokumentasikan apa yang dikatakan dan dilakukan, memilih contoh dan artefak yang sesuai yang menggambarkan kemampuan dan pengetahuan tertentu, dan menggabungkan informasi yang relevan dari keluarga dan orang lain yang bekerja dengan anak tersebut (Meisels et al., 
2010; Mcafee \& Leong, 2011). Pelaksanaan penilaian seperti ini dilakukan guru pada proses pembelajaran konvensional. Namun Selama pembelajaran dilakukan dari rumah, guru tidak dapat melakukan pengamatan langsung mengenai kegiatan yang dilakukan anak didiknya sehingga guru tidak mengetahui secara langsung perkembangan yang terjadi pada anak (Maryani, 2020). Maka untuk memperoleh informasi yang kaya guru harus bekerja sama dengan orang tua dalam mengumpulkan informasi perkembangan anak, karena penilaian otentik adalah kurikulum yang disematkan yaitu, terintegrasi dalam aktivitas sehari-hari yang khas (Mcafee \& Leong, 2011), maka orang tua perlu melaporkan bagaimana prilaku anak sehari dan membantu mendokumentasikan aktivitas bermain anak yang telah dirancang guru untuk dilaksanakan anak di rumah. Pada kegiatan belajar dari rumah, penilaian dilakukan oleh guru menggunakan teknik observasi melalui foto ataupun video yang dikirimkan oleh orang tua dan melalui hasil karya yang dibuat oleh anak (Astuti \& Harun, 2021). Orang tua sebaiknya memiliki keinginan kuat mengembangkan diri agar dapat mendidik anak selama di rumah. Dengan demikian pembelajaran selama pandemi yang dilaksanakan di rumah dapat berlangsung secara efektif (Fauziddin et al., 2021).

Selain itu alat penilaian yang dirancang harus tepat sesuai dengan kondisi pembelajaran daring saat ini. Pengukuran penilaian yang dirancang dengan baik, diterapkan secara efektif, dan ditafsirkan serta digunakan dengan tepat, dapat menginformasikan pengajaran dan berkontribusi pada hasil anak yang lebih baik (Snow \& Van Hemel, 2008). Sebaliknya, apabila penilaian yang dirancang tidak tepat maka dapat mengakibatkan anakanak diberi label yang salah atau tidak menerima dukungan yang sesuai, khususnya pada masa Pandemik Covid -19 saat ini.

Oleh karna itu, penelitian ini bertujuan untuk mengetahui bagaimana pelaksanaan penilaian perkembangan anak selama menerapkan pembelajaran daring di masa pandemic Covid -19. Penelitian difokuskan pada proses pelaksanaan penilaian terkait penggunaan alat penilaian apa yang digunakan guru untuk melihat aspek perkembangan anak, dan bagaimana guru melakukan pengolahan data.

\section{METODOLOGI}

Penelitian ini menggunakan metode analisis deskriptif dengan pendekatan kuantitatif. Dengan menggunakan metode deskriptif kuantitatif peneliti ingin mendapatkan gambaran yang representatif tentang pelaksanaan penlilaian pada anak usia dini selama pembelajaran daring di masa Pandemi Covid -19.

Teknik pengumpulan data pada penelitian ini menggunakan kuesioner. Jenis kuesioner yang digunakan dalam penelitian ini ialah kuesioner terbuka dan kuesioner tertutup. Kuesioner terbuka memberikan kebebasan pada responden untuk memberikan alternatif jawaban. Pada kuesioner terbuka instrument berisi pertanyaan tentang alat penilaian yang dirancang guru untuk mengukur aspek perkembangan anak, pengolahan data yang dilakukan guru dan media dokumentasi yang digunakan orang tua untuk melaporkan kegiatan anak pada guru. Pada kuesioner tertutup responden hanya diperkenankan memlih jawaban yang telah tersedia pada instrument. Dalam instrumen tertutup pertanyan berisi tentang bentuk aktivitas pembelajaran daring dan media yang digunakan untuk melaksankan pembelajaran. Penelitian ini dimulai pada 20 Juni 2020 dengan menyebarkan Kuesioner menggunakan Google Form. Setelah itu tautannya disebarkan melalui aplikasi Whatsapp. Sebelum kuesioner disebarkan, peneliti terbih dahulu meminta izin kepada guru dan menjelaskan tujuan penelitian. Data yang diperoleh selanjutnya dioalah dengan menggunakan docs.google.com, dokumen yang secara langsung telah menghasilkan hasil deskripsi jawaban dari pertanyaan yang telah dijawab oleh responden penelitian.

Responden dalam penilitian ini adalah 23 guru dari 10 Taman Kanak-Kanak dengan menerapkan pembelajaran daring yang berada di beberapa kota dan kabupaten yang berada di Sumatra Utara dengan risiko sedang penyebaran Covid -19 yaitu, Kota Medan, Deli 
Serdang, Serdang berdagai, Asahan, dan Labuhan Batu. Adapun tahap-tahap dalam penelitian akan dijelaskan pada Gambar 1.

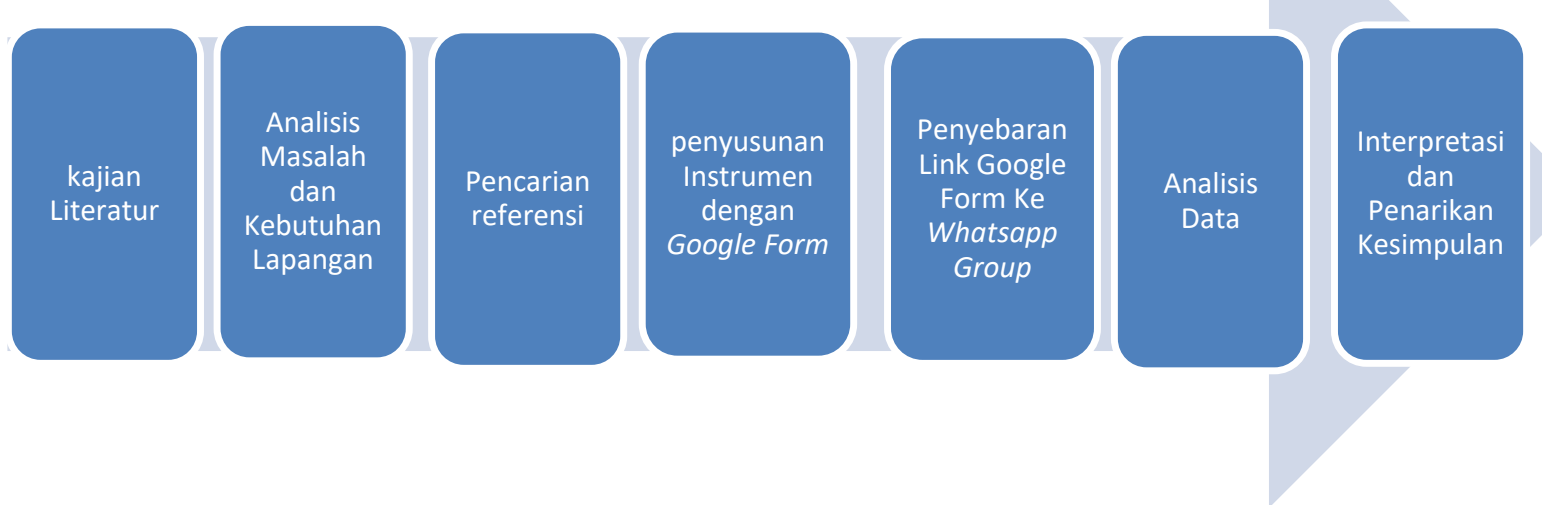

Gambar 1. Langkah-langkah Penelitian

\section{HASIL DAN PEMBAHASAN}

Penilaian merupakan suatu proses pengumpulan, pelaporan, dan penggunaan informasi tentang hasil belajar anak dengan menerapkan prinsip-prinsip penilaian, pelaksanaan, berkelanjutan, bukti-bukti autentik, akurat dan konsisten (Mulyasa, 2013). Dalam melakukan penilaian pada Anak Usia Dini menggunakan berbagai media untuk mengumpulkan informasi, harus bermanfaat bagi anak dan bagi pengembangan pembelajaran, harus melibatkan anak dan keluarganya, harus bersifat objektif bagi semua anak dan harus bersifat otentik. Pelaksanaan penilaian pada anak usia dini dilakukan secara bertahap dan berkesinambungan sehingga kemajuan belajar dan perkembangannya dapat diketahui (Iswantiningtyas \& Wulansari, 2018).

Penilaian pada anak usia dini dilakukan dengan mengadakan suatu pengamatan, pencatatan, dan dokumentasi tentang kegiatan anak. Penilaian tidak hanya digunakan untuk mengukur keberhasilan suatu program, akan tetapi untuk memantau perkembangan belajar anak (Mundia Sari \& Setiawan, 2020). Karna Proses pembelajaran selama pandemic Covid -19 dilakukan di rumah secara daring, maka orang tua yang akan membantu guru dalam mengamati dan mendokumentasikan pertumbuhan dan perkembangan anak. Oleh karna itu meskipun pembelajaran dilakukan dirumah, penilaian tetap harus dilaksanakan melalui kerjasama guru dengan orang tua. Komunikasi yang erat dengan keluarga memberi guru informasi yang berguna tentang anak dan membantu mereka menjembatani konteks perkembangan (Bronfenbrenner, 1986; Mooney, 2013).

Berdasarkan hasil olah data kuesioner tertutup ditemukan selama pembelajaran dilaksanakan secara daring dari rumah di masa pandemic para guru dari 10 sekolah yang diamati tetap meksanakan penilaian. Selain itu, selama masa pandemic agar bisa dilakukan penilaian maka guru melakukan beberapa bentuk aktivitas utama dalam pelaksanaan pembelajaran.

Gambar 1 menggambarkan bentuk aktivitas proses pelaksanaan pembelajaran oleh guru yaitu sebesar $41 \%$ guru melaksanakan pembelajaran dengan penugasan. Proses penugasan dilakukan guru dengan memberikan beberapa aktivitas untuk dilakukan anak di rumah. Selanjutnya, 11\% guru melakukan Home Visit. Guru melaksanakan Home Visit dengan berkunjung ke rumah anak secara rutin dengan menyusudn jadwal dan bergantian setiap anak. Proses Home Visit ini menjadi penting dikarenakan salah satu cara agar aspek perkembangan anak bisa terus dimonitor sehingga aktivitasnya berhasil terlaksana dengan baik (Nahdi, dkk., 2020). Selanjutnya ada $26 \%$ guru melakukan penugasan dan laporan harian kegiatan perkembangan anak, dan $8,4 \%$ guru melakukan kombinasi dari penugasan, Home 
Visit, dan laporan kegiatan anak. Dari jawaban responden dapat ditemukan aktifitas pembelajaran yang paling banyak dilaksanakan guru adalah penugasan. Hasil ini juga sejalan dengan penelitian Muhdi \& Nurkholis (2020) bahwa metode yang digunakan pada e-learning di PAUD adalah 95\% penugasan walaupun dilengkapi dengan metode lainnya.

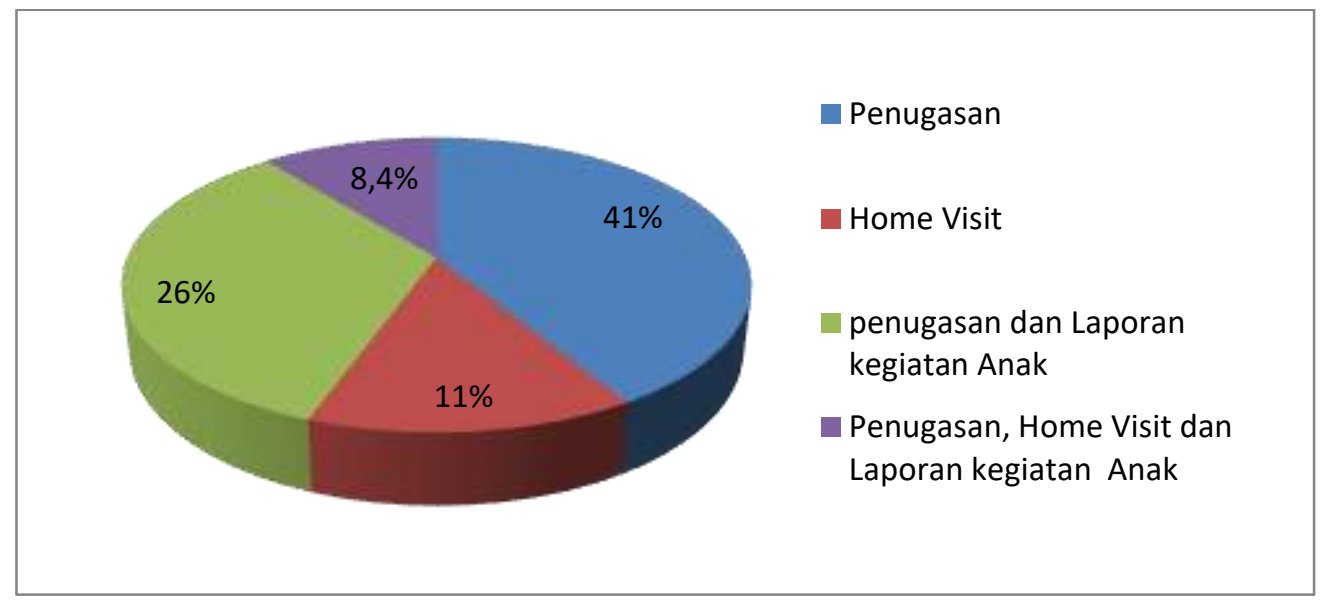

Gambar 2. Bentuk Aktivitas Proses Pelaksanaan Pembelajaran

Selain proses pembelajaran jarak jauh yang dilakukan dari rumah secara daring tentunya membutuhkan media yang dapat digunakan untuk mengakomendasi pembelajaran daring (Nasution \& Sutapa, 2021), dalam memilih media online yang tepat perlu memperhitungkan tingkat perkembangan anak untuk menemukan perangkat pembalajaran online yang sesuai dan yang dapat mempromosikan partisipasi dan pembelajaran anak (Kim, 2020). Pilihan Media media onlie yang digunakan guru selama proses pembelajaran daring dapat dilihat pada Gambar 3.

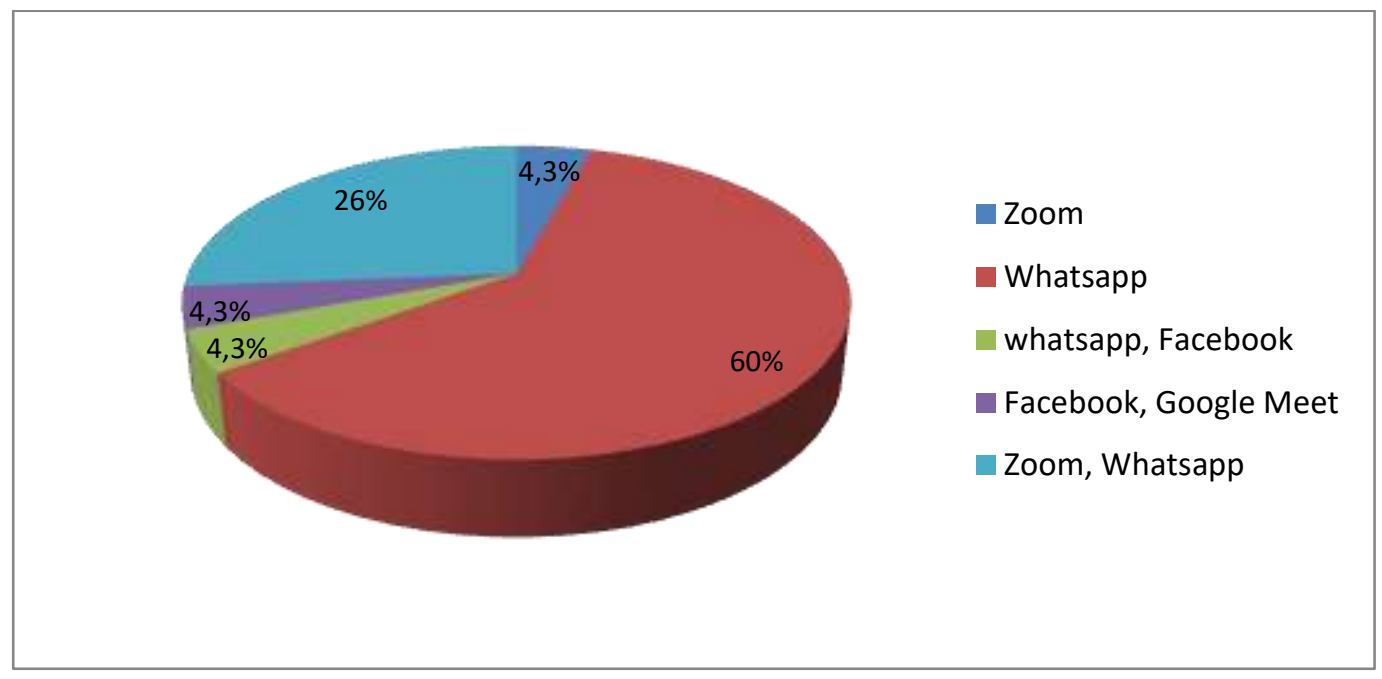

Gambar 3. Media Yang Digunakan Guru Selama Proses Pembelajaran Daring

Selain mengakomendasi pembelajaran, penggunaan media online tentunya dibutuhkan untuk menjebatani komunikasi antara guru dan orang tua terkait perkembangan anak selama belajar dari rumah. Pada diagram 1 ditunjukkan bahwa media online yang paling banyak digunakan guru selama pembelajaran daring ialah media Whatsapp yaitu sebanyak $60 \%$ guru. Selanjutnya $26 \%$ guru menggunakan media Zoom dan Whatsapp, 4,3\% guru menggunakan media Zoom, 4,3 \% guru menggunakan media Whatsapp dan Facebook, dan terakhir 4,3\% guru menggunakan Facebook dan Google Meet. Dalam hal ini dapat diartikan para guru yang melakukan pembelajaran daring sudah menyesuaikan diri dengan penggunaan 
teknologi selama masa pembelajaran jarak jauh, selain itu guru sudah mulai mampu memilih media sesuai kebutuhan. Hal ini terlihat dari kombinasi media yang digunakan guru seperti menggunakan zoom untuk melakukan pertemuan online dengan anak dan menggunakan whatsapp untuk berkomunikasi dan berbagi informasi dengan orang tua. Teknologi informasi dan komunikasi (TIK) dalam pendidikan kontemporer menawarkan potensi untuk memberikan kegiatan kreatif dan komunikatif untuk anak (Kim, 2020). Maka penting bagi guru untuk perhatian tentang cara menyediakan lingkungan online yang aman dan sehat yang sesuai untuk anak-anak, untuk mengembangkan keterampilan berpikir dan pemahaman mereka tentang teknologi untuk pembelajaran di abad ke-21 (Mantilla et al., 2018).

\section{Proses Pelaksanaan Penilaian Perkembangan Anak}

Proses penilaian dilakukan pada saat anak melakukan berbagai kegiatan (Mundia Sari \& Setiawan, 2020; Wahyudi, 2015). Kegiatan yang dilakukan anak berperan penting dalam menggambarkan perkembangan anak, maka selama pembelajaran dilakukan dari rumah guru harus menyampaikan pesan yang jelas mengenai kegiatan-kegiatan yang dapat dilakukan anak di rumah kepada orang tua, agar orang tua dapat memberikan informasi perkembangan anak secara efektif. Melalui informasi yang diberikan orang tua guru dapat melakukan penilaian melalui berbagai informasi yang berhubungan dengan aspek pertumbuhan fisik dan 6 aspek perkembangan, yaitu nilai agama dan moral, perkembangan fisik motorik (gerakan motorik kasar dan halus, serta kesehatan fisik), perkembangan kognitif, bahasa, sosial emosional, dan seni (Direktorat PAUD, 2020). Proses pelaksanaan penialaian perkembangan yang dilakukan oleh guru selama belajar dari rumah di masa Pandemik dapat dilihat pada Tabel 1.

Tabel 1. Proses Pelaksanaan Penilaian

\begin{tabular}{|c|c|c|}
\hline \multirow[t]{2}{*}{ Deskripsi Pertanyaan } & \multicolumn{2}{|c|}{ Alternatif Jawaban Lebih Dari 1} \\
\hline & Terbanyak $1(\%)$ & Terbanyak 2 (\%) \\
\hline $\begin{array}{l}\text { Bentuk kegiatan yang digunakan dalam } \\
\text { peroses pembelajaran }\end{array}$ & Lembar kerja $(56,7)$ & $\begin{array}{l}\text { Lembar kerja } \\
\text { Performa (26) }\end{array}$ \\
\hline $\begin{array}{l}\text { Dokumentasi yang digunakan untuk merekam } \\
\text { kegiatan dan proses pembelajaran anak }\end{array}$ & Video dan Photo $(65,2)$ & Photo $(34,7)$ \\
\hline $\begin{array}{l}\text { Alat penilian yang digunakan untuk } \\
\text { mengakses perkembangan anak }\end{array}$ & $\begin{array}{l}\text { Observasi } \\
\text { Portofolio }(43,4)\end{array}$ & Portofolio $(30,4)$ \\
\hline $\begin{array}{l}\text { Alat bantu penilaian yang digunakan untuk } \\
\text { merekam prilaku anak }\end{array}$ & $\begin{array}{l}\text { Catatan hasil karya } \\
(39,1)\end{array}$ & Daftar Chek $(30,4)$ \\
\hline
\end{tabular}

Ditinjau dari bentuk aktivitas utama yang paling banyak dilakukan guru adalah dengan penugasan. Maka kegiatan dalam peugasan yang paling banyak dilakukan guru ialah dengan memberikan lembar kerja. Sebanyak 56,7\% guru memberikan penugasan dalam bentuk lembar kerja. Selanjutnya $26 \%$ guru memberi kegiatan dalam bentuk lembar kerja dan Perfome (unjuk kerja), 17,3\% guru memberikan kegiatan dalam bentuk lembar kerja dan proyek. Bentuk kegiatan dalam lembar kerja yang diberikan guru mengarah pada penggambaran aspek kognitif, bahasa, motorik halus, dan seni anak. Beberapa contoh kegiatan dalam lembar kerja yang diberikan guru ialah menulis, menghitung, menggambar, melipat, menggunting dan menempelkan. Sedangkan perfome (unjuk kerja) mengarah pada penggambaran fisik, motorik kasar, emosional, dan nilai agama. Beberapa contoh kegiatan dengan unjuk kerja seperti mengikuti contoh senam dan gerak tari melalui video yang diberikan guru, hafalan surah pendek, dan praktek ritual keagamaan seperti sholat.

Selama kondisi pandemic Covid -19 ini guru dapat meminta orangtua untuk mengirimkan foto-foto hasil karya anak atau video proses kegiatan anak di rumah (Direktorat PAUD, 2020). Berdasarkan jawaban responden, $65,2 \%$ guru meminta orang tua melaporkan proses dan hasil kegiatan anak dalam bentuk dokumentasi video dan foto, dan sebanyak 
$34,7 \%$ hanya meminta foto saja. Dari jawaban responden, dokumentasi dalam bentuk foto digunakan untuk melaporkan hasil kegiatan anak berupa hasil karya. Sedangkan dokumentasi video berupa rekaman proses kegiatan anak dan digunakan untuk mendokementasikan kegiatan perfome atau unjuk kerja.

Berdasarkan jawaban responden, metode yang digunakan guru dalam melakukan penilaian ialah $43,4 \%$ observasi dan portofolio secara bersamaan. Selanjutnya $30,4 \%$ guru menggunakan portofolio, dan sebanyak $26 \%$ guru menggunakan observasi saja. Observasi dilaksanakan ketika guru melakukan pertemuan melalui zoom, dimana guru mengamati prilaku anak mulai dari awal hingga akhir pertemuan tersebut. Selain itu, observasi juga dilakukan guru melalui video unjuk kerja yang dikirim orang tua selama proses pembelajaran anak di rumah. Observasi merupakan penilaian yang dilakukan dengan mengamati prilaku dan aktivitas anak dalam satu waktu kegiatan (Yus, 2015), selanjutnya prilaku anak tersebut dibandingkan dengan kriteria sesuai tingkat usia anak (Wahyudi, 2015). Sedangkan portofolio dilakukan guru dengan mengumpulkan hasil kerja anak baik itu lembar kerja maupun hasil karya anak untuk dilakukan penilaian. Menurut Barret (2007) portofolio pendidikan akan berisi karya dan bukti lainnya (dalam PAUD ini akan menjadi hal-hal seperi karya seni) yang telah dikumpulkan oleh anak dan orang lain seperi guru dari waktu ke waktu (Hooker, 2019). Guru menyimpan portofolio dengan mengumpulkan contoh-contoh pekerjaan yang dihasilkan anak, seperti perkembangan seni, gambar, menulis, berhitung, dan perkembangan lainnya (Hartati \& Zulminiati, 2020), semakin lengkap isi portfolio maka semakin lengkap data yang dapat dijadikan pedoman dalam melakukan penilaian dan evaluasi tingkat perkembangan atau hasil belajar yang telah dicapai anak (Wahyudi, 2015). Dari jawaban responden selama pandemic ini portofolio yang dikumpulkan beralih ke bentuk dokumentasi elektronik yaitu foto hasil lembar kerja, hasil karya anak, dan video unjuk kerja anak yang disatukan dalam bentuk file.

Selanjutnya kumpulan Data yang berkaitan dengan hasil karya dan prilaku anak yang diamati melaui foto dan video direkam dalam berbagai bentuk rekaman perkembangan anak. Ditinjau dari hasil jawaban responden ditemukan sebanyak 39,1\% guru menggunakan penilaian hasil karya dan daftar chek list. Selanjutnya 30,4\% guru menggunakan catatan hasil karya, sebanyak 17,3\% daftar chek list, 13\% guru menggunakan skala penilaian. Hasil karya adalah hasil kerja anak didik setelah melakukan suatu kegiatan dapat berupa pekerjaan tangan, karya seni atau tampilan anak (Zahro, 2015). Dikarenakan selama masa pandemic sebagian besar guru menggunakan bentuk kegiatan berupa penugasan dengan menggunakan lembar kerja maka bentuk rekaman perkembangan anak yang digunakan guru ialah berupa penilain hasil karya anak. Guru melakukan pengamatan terhadap hasil karya anak dan mencatat hasil pengamatannya serta indikator dari kompetensi dasar yang telah dicapai anak. Sedangkan skala penilaian salah satu bentuk teknik dan prosedur yang dilakukan untuk mengukur perkembangan anak usia dini (Wahyudi, 2015).

Berdasarkan hasil jawaban responden yang dirangkum pada tabel 1 ditemukan bahwa bentuk kegiatan yang paling banyak digunakan guru selama proses pembelajaran daring adalah penugasan dalam benuk lembar kerja dan unjuk kerja (performe). Untuk melaporkan proses kegiatan dan hasil kegiatan anak hamper semua guru meminta orang tua untuk mengirim laporan berupa dokumentasi photo dan video. Sedangkan alat penilaian yang paling banyak digunakan guru untuk mengakses perkembangan anak selama pembelajaran daring di masa pandemic ini ialah observasi dan portofolio. Untuk mendokumentasikan perkembangan anak maka sebagian besar guru menggunakan alat rekam penilaian hasil karya dan daftar checklist.

\section{Pengolahan Data Perkembangan Anak}

Penilaian pada proses pembelajaran anak usia dini selama pandemic COVID-19 dilakukan dengan mengumpulkan data atau informasi terkait prilaku dan hasil kegiatan anak selama proses pembelajaran dalam bentuk portofolio. Selanjutnya data atau informasi 
tersebut akan dilakukan analisis oleh guru untuk memperoleh kesimpulan tentang gambaran akhir anak berdasarkan semua indikator yang telah ditetapkan (Wahyudi, 2015). Bukti penilaian harus dikumpulkan dari waktu ke waktu, dari berbagai sumber termasuk keluarga, dalam lingkungan alami sehingga secara akurat mencerminkan dan mendukung perkembangan dan pembelajaran anak (Lambert et al., 2015). Pengolahan data dapat dilakukan secara berkala (mingguan atau bulanan) (Direktorat PAUD, 2020). Waktu Pengolahan data perkembangan anak digambarkan pada Gambar 4.

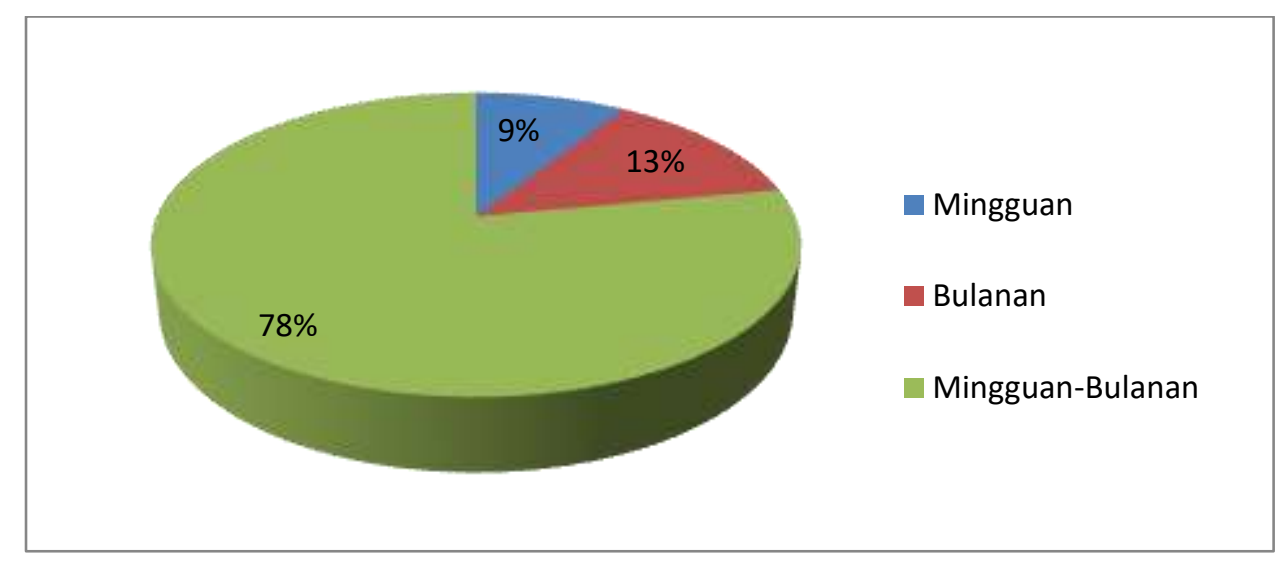

Gambar 4. Waktu Pengolahan Data Perkembangan Anak

Dari hasil jawaban responden ditemukan jawaban bahwa sebanyak $78 \%$ guru melakukan pengolahan data secara berkala yaitu mingguan bulanan. Selanjutnya $13 \%$ guru melakukan pengolahan data hanya bulanan saja, dan $9 \%$ guru melakukan pengolahan data hanya mingguan. Guru yang melakukan pengolahan data secara berkala merangkum data harian anak perminggu. Data yang dikumpulkan disusun berdasarkan tanggal dan identitas anak. Selama masa pandemic guru menyimpan data pertumbuhan dan perkembangan anak dalam bentuk file di dalam satu folder penilaian dan masing-masing anak memiliki folder tersendiri.

Selanjutnya data yang terkumpul setiap minggu dimasukkan dalam format bulanan dan melihat capaian tertinggi yang dicapai anak sepanjang bulan tersebut untuk menentukan capaian akhir dalam sebulan. Capaian akhir pada pada sepanjang bulan dimasukkan guru pada format bulanan untuk setiap bulan selama satu semester pada format penilaian akhir semester dan guru memilih capaian tertinggi yang telah dicapai oleh anak dari sepanjang bulan untuk menentukan capaian akhir semester. Sedangkan guru yang melakukan pengolahan data secara bulanan, dalam menentukan capaian perkembangan anak dengan melihat capaian terakhir anak pada minggu terakhir dari setiap bulan dan dalam menentukan capaian akhir semester berdasarkan capaian terakhir anak dari akhir bulan di semester tersebut. Dan sebagian guru melakukan pengolahan data setiap minggu dan tidak menggunakan format bulanan.

Dari semua sekolah yang diteliti ditemukan bahwa semua sekolah melakukan pelaporan hasil penilaian setiap akhir semester. Pada saat menyampaikan laporan perkembangan anak, guru dapat menyampaikan hal-hal berikut: 1 . Keadaan anak waktu belajar secara fisik, sosial, dan emosional 2. Kemampuan/kompetensi yang sudah dan belum dikuasai anak. 3. Hal-hal yang harus dilakukan orang tua untuk membantu dan mengembangkan anak lebih lanjut (Direktorat PAUD, 2020). Selama masa pandemic ini guru melaporkan hasil penilaian perkembangan anak dengan laporan berbentuk file yang dikirimkan pada masing-masing orang tua melalui Whatsapp. Selain itu pelaporan juga dilakukan dengan langsung mengkomunikasikan hasil perkembangan anak secara pribadi dengan melakukan home visit oleh guru. 


\section{SIMPULAN}

Hasil penelitian menunjukkan bahwa penilaian tetap dilaksanakan meski pembelajaran dilakukan secara daring dari rumah. Penilaian dilakukan guru melalui kerjasama dengan orang tua. Penilaian dilakukan berdasarkan laporan yang diberikan orang tua dalam bentuk dokumntasi elektronik. Alat penilaian yang digunakan bervariasi dan dikombinasikan sesuai kebutuhan seperti menggunakan observai dan portofolio secara bersamaan. Alat bantu penilaian yang digunakan untuk merekam proses perkembangan anak juga sangat bervariasi seperti catatan hasil karya dan daftar checklist. Pengolah data yang dilakukan guru juga beragam ada yang dilakukan secara berkala dengan format mingguan dan bulanan dan ada juga yang hanya dilakukan mingguan saja dan bulanan saja.

\section{UCAPAN TERIMA KASIH}

Terimakasih kepada guru-guru PAUD yang telah bersedia menjadi responden pada penelitian yang dilakukan sehingga membantu jalannya proses penulisan artikel ini . Selanjutnya terimakasi kepada bapak Dr. Drs. Arif Rohman, M.Si. selaku dosen pembimbing dalam penulisan artikel ini. Serta kepada tim redaksi jurnal obsesi yang telah memberikan masukan untuk peningkatan kualitas penulisan artikel ini.

\section{DAFTAR PUSTAKA}

Ayuni, D., Marini, T., Fauziddin, M., \& Pahrul, Y. (2021). Kesiapan Guru TK Menghadapi Pembelajaran Daring Masa Pandemi Covid-19. Jurnal Obsesi : Jurnal Pendidikan Anak Usia Dini, 5(1), 414-421. https://doi.org/10.31004/obsesi.v5i1.579 https:// doi.org/10.31004/obsesi.v5i1.579

Bronfenbrenner, U. (1986). Ecology of the Family as a Context for Human Development. Research Perspectives. Developmental Psychology, 22(6), 723-742. https:// doi.org/10.1037/0012-1649.22.6.723

Cichoracki, D. J. (2013). Exploring the Knowledge Gap in Early Childhood Assessment.

Fauziddin, M., Mayasari, D., \& Rizki, L. M. (2021). Effective Learning for Early Childhood during Global Pandemic. Al-Ishlah: Jurnal Pendidikan, 13(1). https:// doi.org/10.35445/alishlah.v13i1.458

Hartati, S., \& Zulminiati, Z. (2020). Fakta-Fakta Penerapan Penilaian Otentik di Taman KanakKanak Negeri 2 Padang. Jurnal Obsesi : Jurnal Pendidikan Anak Usia Dini, 5(2), 10351044. https://doi.org/10.31004/obsesi.v5i2.521

Hooker, T. (2019). Using ePortfolios in early childhood education: Recalling, reconnecting, restarting and learning. Journal of Early Childhood Research, 17(4), 376-391. https:// doi.org/10.1177/1476718X19875778

Iswantiningtyas, V., \& Wulansari, W. (2018). Pentingnya Penilaian Pendidikan Karakter Anak Usia Dini. Proceedings of the ICECRS, 1(3), 197-204.

https:// doi.org/10.21070/picecrs.v1i3.1396

Kemendikbud, R. I. (2020). Penilaian Perkembangan Anak Selama Belajar.

Kim, J. (2020). Learning and teaching online during Covid-19: experiences of student teachers in an early childhood education practicum. International Journal of Early Childhood, 52(2), 145-158. https:/ / doi.org/10.1007/s13158-020-00272-6

Lambert, R. G., Kim, D. H., \& Burts, D. C. (2015). The measurement properties of the Teaching Strategies GOLD® assessment system. Early Childhood Research Quarterly, 33, 49-63. https://doi.org/10.1016/j.ecresq.2015.05.004

Mantilla, S. E. A., Henderson, M., Skouteris, A. N. H., \& Plowman, L. (2018). Teacher practices for building young children's concepts of the internet through play-based learning. Educational Practice and Theory, 40(1), 29-50. https://doi.org/10.7459/ept/40.1.03 
DOI: 10.31004/obsesi.v6i2.1129

Maryani, K. (2020). Penilaian dan Pelaporan Perkembangan Anak Saat Pembelajaran di Rumah di Masa Pendemi Covid-19. Murhum, 1(2), 41-52. https://doi.org/10.37985/murhum.v1i1.4

Meisels, S. J., Wen, X., \& Beachy-Quick, K. (2010). Authentic assessment for infants and toddlers: Exploring the reliability and validity of the ounce scale. Applied Developmental Science, 14(2), 55-71. https:// doi.org/10.1080/10888691003697911

Mooney, C. (2013). Chapter 2: Maria Montessori Montessori 's Theories Child-Centered Environments. Theories of Childhood: An Introduction to Dewey, Montessori,, Erikson, Piaget and Vygotsky.

Mulyasa. (2013). Pengembangan dan Implementasi kurikulum 2013. Bandung: Remaja Rosadakarya, 10-45.

Mundia Sari, K., \& Setiawan, H. (2020). Kompetensi Pedagogik Guru dalam Melaksanakan Penilaian Pembelajaran Anak Usia Dini. Jurnal Obsesi : Jurnal Pendidikan Anak Usia Dini, 4(2), 900. https:// doi.org/10.31004/obsesi.v4i2.478

Nasution, S. T., \& Sutapa, P. (2021). Strategi Guru dalam Menstimulasi Keterampilan Motorik AUD Pada Era Pandemi Covid 19. 5(2), 1313-1324. https://doi.org/10.31004/obsesi.v5i2.849

Nurkolis, N., \& Muhdi, M. (2020). Keefektivan Kebijakan E-Learning berbasis Sosial Media pada PAUD di Masa Pandemi Covid-19. Jurnal Obsesi : Jurnal Pendidikan Anak Usia Dini, 5(1), 212. https:// doi.org/10.31004/obsesi.v5i1.535

Rohmadheny, P. S., Nuraini, F. T., \& Setyaningrum, I. (2019). What are the Problems of Indonesian ECE Teachers in the Implementation of Learning Evaluation? International Conference on Early Childhood Development (ICECD), 2019, 24-28.

Trisnawati, W., \& Sugito, S. (2020). Pendidikan Anak dalam Keluarga Era Covid-19. Jurnal Obsesi: Jurnal Pendidikan Anak Usia Dini, 5(1), 823-831. https://doi.org/10.31004/obsesi.v5i1.710

Wahyudi, M. D. (2015). Implementasi Authentic Assessment Di Paud. Prosiding Seminar Nasional PS2DMP UNLAM, 1(1), 17-26.

Yus, A. (2015). Penilaian Perkembangan Belajar Anak Taman Kanak-kanak. In Penilaian Perkembangan Belajar Anak Taman Kanak-kanak. Kencana.

Zahro, I. F. (2015). Penilaian dalam Pembelajaran Anak Usia Dini. Tunas Siliwangi. 